Boise State University

ScholarWorks

Early and Special Education Faculty

Publications and Presentations

Department of Early and Special Education

$1-5-2022$

\title{
A Systematic Review of Research Syntheses for Students with Mathematics Learning Disabilities and Difficulties
}

Gena Nelson

Boise State University

Angela Crawford

Boise State University

Jessica Hunt

North Carolina State University

Publication Information

Nelson, Gena; Crawford, Angela; and Hunt, Jessica. (2022). "A Systematic Review of Research Syntheses for Students with Mathematics Learning Disabilities and Difficulties". Early and Special Education Faculty Publications and Presentations, article no. 143, pp. 1-21. https://doi.org/10.18122/sped.143.boisestate 
A Systematic Review of Research Syntheses for Students with Mathematics Learning Disabilities and Difficulties

\begin{abstract}
The purpose of this document is to provide readers with the coding protocol that authors used to code 36 research syntheses (including meta-analyses, evidence-based reviews, and quantitative systematic reviews) focused on mathematics interventions for students with learning disabilities (LD), mathematics learning disabilities (MLD), and mathematics difficulties (MD). The purpose of the systematic review of mathematics intervention syntheses was to identify patterns and gaps in content areas, instructional strategies, effect sizes, and definitions of LD, MLD, and MD. We searched the literature for research syntheses published between 2000 and 2020 and used rigorous inclusion criteria in our literature review process. We evaluated 36 syntheses that included 836 studies with 32,495 participants. We coded each synthesis for variables across seven categories including: publication codes (authors, year, journal), inclusion and exclusion criteria, content area focus, instructional strategy focus, sample size, methodological information, and results. The mean interrater reliability across all codes using this coding protocol was $90.3 \%$. Although each synthesis stated a focus on LD, MLD, or MD, very few students with LD or MLD were included, and authors' operational definitions of disability and risk varied. Syntheses predominantly focused on word problem solving, fractions, computerassisted learning, and schema-based instruction. Syntheses reported wide variation in effectiveness, content areas, and instructional strategies. Finally, our results indicate the majority of syntheses report achievement outcomes, but very few syntheses report on other outcomes (e.g., social validity, strategy use). We discuss how the results of this comprehensive review can guide researchers in expanding the knowledge base on mathematics interventions.
\end{abstract}

The systematic review that results from this coding process is accepted for publication and in press at Learning Disabilities Research and Practice.

Keywords: meta-analysis, mathematics, intervention, learning disability, coding protocol

Nelson, Crawford \& Hunt (2022) Copyright 


\section{Math Intervention Research Synthesis Coding Rubric}

Please keep in mind that for coding purposes in this study, we use the following:

- $\quad \mathrm{MD}$ (risk) = mathematics difficulty; low achievement in math; learning difficulty in math; risk in math

- $\quad$ MLD $($ disability $)=$ mathematics learning disability; math disability; dyscalculia; LD with IEP goal in math

Some of the codes that required copy/paste were used for descriptive information or were recoded for qualitative themes.

This coding protocol includes variables in the following categories:

- Publication codes (p. 2)

- Inclusion and exclusion criteria (p. 2)

- Content area, stated focus of the synthesis (p. 5)

- Instructional strategies, stated focus of the synthesis (p. 8)

- Student participant demographics including Md and MLD identification (p. 11)

- Methodological information and results (p. 13)

- Instructional strategy, other results (p. 17)

- How effectiveness was measured and reported (p. 20)

Publication Codes

\begin{tabular}{|l|l|l|l|}
\hline Cell & Variable & Code & Explanation \\
\hline A & Authors & Name & List all authors' last names \\
\hline B & Year & Number & Record year of publication \\
\hline C & Journal & Name & Record journal; Use full name, do not use acronyms \\
\hline
\end{tabular}

\section{PURPOSE AND FOCUS OF THE SYNTHESIS}

\section{Inclusion and Exclusion Criteria}

Note: These codes are related to the author's purpose of the synthesis and inclusion and exclusion criteria, not on the specific results or description of included studies in the meta-analysis.

\begin{tabular}{|l|l|l|}
\hline Variable & Code & Explanation \\
\hline
\end{tabular}

Nelson, Crawford \& Hunt (2022) Copyright 


\begin{tabular}{|c|c|c|}
\hline Grade/Age & $\begin{array}{l}\text { Copy/Paste Information or } \\
\text { NA }\end{array}$ & $\begin{array}{l}\text { Copy and paste inclusion and exclusion criteria related to the age or } \\
\text { grade of participants. If authors did not state inclusion or exclusion } \\
\text { criteria related to age or grade, write N/A. }\end{array}$ \\
\hline Outcome Measure & $\begin{array}{l}\text { Copy/Paste Information or } \\
\text { NA }\end{array}$ & $\begin{array}{l}\text { Copy and paste inclusion and exclusion criteria related outcome } \\
\text { measure requirements. If authors did not state inclusion or exclusion } \\
\text { criteria related to outcome measures, write N/A. }\end{array}$ \\
\hline $\begin{array}{l}\text { Participant Disability } \\
\text { or Risk as Specified in } \\
\text { Method }\end{array}$ & Copy and Paste Information & $\begin{array}{l}\text { Copy and paste the specific requirement that authors state related to } \\
\text { including studies. Copy and paste information such as "studies were } \\
\text { required to include at least one student with LD" or "Studies were } \\
\text { required to include participants who performed below the } 25^{\text {th }} \\
\text { percentile on a standardized measure of achievement." Or }\end{array}$ \\
\hline $\begin{array}{l}\text { Participant LD/MLD } \\
\text { Criteria }\end{array}$ & $\begin{array}{l}\text { Select all that apply related } \\
\text { to disability requirement: } \\
0=\text { Not Applicable } \\
1=\text { percentile cutoff } \\
2=\text { IDEA, school, district, or } \\
\text { state criteria } \\
3=\text { documented } \\
4=\text { IEP goal } \\
5=\text { Services in special } \\
\text { education setting } \\
6=\text { Other } \\
7=\text { Not described } \\
\text { Separate responses using a } \\
\text { semi-colon (e.g., "1; } 3 ; 4 \text { ") }\end{array}$ & $\begin{array}{l}\text { These codes specifically refer to how authors identified or described } \\
\text { their definition of learning disabilities or mathematics learning } \\
\text { disabilities. Codes defined as: } \\
\text { - Not applicable = The authors did not include participants with } \\
\text { LD/MLD (disability) in their synthesis, they only included } \\
\text { Math Difficulty. } \\
\text { - Percentile = authors used a percentile to state students had } \\
\text { LD/MLD, such as performing below the 10th percentile on a } \\
\text { measure of math achievement. } \\
\text { - IDEA, School, district, or state criteria = Authors stated that } \\
\text { participants had LD/MLD according to a set of criteria } \\
\text { - Documented = Authors stated that the participants had a } \\
\text { documented LD/MLD (e.g., "students with documented MLD } \\
\text { were included.") } \\
\text { - IEP = Authors stated that the participants that had IEPs goals in } \\
\text { math } \\
\text { - Special education = Authors stated that students received } \\
\text { special education services in mathematics } \\
\text { Other = Authors used other criteria and specified what criteria } \\
\text { were (e.g., a statement that they used the criteria identified in } \\
\text { the original study, "The study included a subset of participants } \\
\text { as have a learning disability." Not described = Authors stated }\end{array}$ \\
\hline
\end{tabular}

Nelson, Crawford \& Hunt (2022) Copyright 


\begin{tabular}{|c|c|c|}
\hline & & $\begin{array}{l}\text { that students with LD/MLD were a focus of their study, but the } \\
\text { authors did not provide the criteria they used (authors of the } \\
\text { synthesis may also state something like, "students were } \\
\text { identified with MLD with methods as described by the author" } \\
\text { although, the specific criteria are still not described). }\end{array}$ \\
\hline $\begin{array}{l}\text { Participant LD/MLD } \\
\text { Criteria: PERCENTILE }\end{array}$ & Number or N/A & $\begin{array}{l}\text { If the synthesis identified participants with MLD using a percentile } \\
\text { cutoff (code of } 1 \text { above), provide the percentile (use pc. and }<\text { or }<=\text { ) } \\
\text { Examples: } \\
\begin{array}{l}\text { - } \quad<35 \mathrm{pc} \\
\text { - } \quad<=25 \mathrm{pc} \\
\text { - } 11 \text { to } 25 \mathrm{pc}\end{array}\end{array}$ \\
\hline $\begin{array}{l}\text { Participant LD/MLD } \\
\text { Criteria: OTHER }\end{array}$ & $\begin{array}{l}\text { NA or Anecdotal (fill out } \\
\text { anecdotal only if you marked } \\
\text { code of "6" above) }\end{array}$ & $\begin{array}{l}\text { If the synthesis identified participants with MLD using a "other" } \\
\text { criteria, copy and paste the criteria here. }\end{array}$ \\
\hline $\begin{array}{l}\text { Participant Math } \\
\text { Difficulty (MD) or } \\
\text { Risk Criteria }\end{array}$ & $\begin{array}{l}\text { Select all that apply: } \\
0=\text { Not applicable } \\
1=\text { percentile cut off on a } \\
\text { screening test or measure } \\
2=\text { teacher or parent referral } \\
\text { or identification } \\
3=\text { state test scores/ } \\
\text { benchmark } \\
4=\text { Receiving Intervention } \\
5=\text { Other } \\
6=\text { Not Described } \\
\text { Separate responses using a } \\
\text { semi-colon (e.g., " } 1 ; 3 ; 4 \text {;") }\end{array}$ & $\begin{array}{l}\text { These codes specifically refer to how authors identified or described } \\
\text { their definition of DIFFICULTY or RISK. Codes defined as: } \\
\text { - Not applicable = The authors did not include participants with } \\
\text { MD (risk) in their synthesis, they only included disability. } \\
\text { - Percentile = authors used a percentile to state students had MD, } \\
\text { such as performing below the } 25 \text { th percentile on a measure of } \\
\text { achievement. } \\
\text { - Referral = parents or teachers referred students for MD } \\
\text { - State test = Authors stated that participants had MD according } \\
\text { to a score on a state test } \\
\text { - Receiving Intervention = Authors stated that students were } \\
\text { included as MD due to receiving targeted services, intervention, } \\
\text { Tier } 2,3 \text {, etc. } \\
\text { - Other = Authors used other criteria and specified what criteria } \\
\text { were (e.g., a statement that the authors used the criteria } \\
\text { identified in the original study such as "We included any study } \\
\text { where authors specified that students had MD.") } \\
\text { Not described = Authors stated that students with MD were a } \\
\text { focus of their study, but the authors did not provide difficulty }\end{array}$ \\
\hline
\end{tabular}

Nelson, Crawford \& Hunt (2022) Copyright 


\begin{tabular}{|l|l|l|}
\hline & & $\begin{array}{l}\text { criteria they used (authors of the synthesis may also state that } \\
\text { students were identified with MD with methods 'as described } \\
\text { by the author' although, the specific criteria are still not } \\
\text { described). }\end{array}$ \\
\hline $\begin{array}{l}\text { Participant Math } \\
\text { Difficulty Criteria: } \\
\text { PERCENTILE }\end{array}$ & Number or NA & $\begin{array}{l}\text { Code defined: } \\
\text { If the synthesis identified participants with MD using a percentile } \\
\text { cutoff (code of 1 above), provide the percentile (use pc. and }<\text { or }<=\text { ) } \\
\text { Examples: } \\
\bullet<35 \text { pc } \\
<=25 \text { pc } \\
11 \text { to } 25 \text { pc }\end{array}$ \\
\hline $\begin{array}{l}\text { Participant Math } \\
\text { Difficulty Criteria: } \\
\text { OTHER }\end{array}$ & $\begin{array}{l}\text { NA or Anecdotal (fill out only } \\
\text { if you marked code of "5") }\end{array}$ & $\begin{array}{l}\text { If the synthesis identified participants with MD using an "other" } \\
\text { criteria, copy and paste the criteria here. }\end{array}$ \\
\hline
\end{tabular}

\section{Content Area Focus: As the Stated Purpose of the Synthesis}

Note: These codes are related to the author's purpose of the synthesis and inclusion and exclusion criteria, not on the specific results or description of included studies in the meta-analysis.

\begin{tabular}{|l|l|l|}
\hline Variable & Code & Explanation \\
\hline $\begin{array}{l}\text { Content Area as } \\
\text { Specified in Purpose }\end{array}$ & Copy and Paste Information & $\begin{array}{l}\text { Copy and paste information from the purpose or inclusion and exclusion } \\
\text { criteria about the focus of the synthesis (perhaps this would be in the title } \\
\text { as well). This will help you determine which content areas to select "yes" } \\
\text { for below. }\end{array}$ \\
\hline Broad Math & Two Codes, See Below & $\begin{array}{l}\text { Some meta-analysis or reviews might simply state that they focused on } \\
\text { "math interventions" without any follow up information, this is an } \\
\text { example of when this code would be "yes" Or, some studies might say } \\
\text { that they focused on Number and Operations skills (which encompass } \\
\text { many different mathematics skills), this would also be a code a "yes" }\end{array}$ \\
\hline Early Numeracy & Two Codes, See Below & $\begin{array}{l}\text { This includes number sense, place value, counting, number } \\
\text { identification, subitizing, decomposing and composing, early math, etc. }\end{array}$ \\
\hline $\begin{array}{l}\text { Basic Facts, } \\
\text { Computation }\end{array}$ & Two Codes, See Below & $\begin{array}{l}\text { This includes interventions focused on operations: basic facts, } \\
\text { computation, number combinations (including addition, subtraction, }\end{array}$ \\
\hline
\end{tabular}

Nelson, Crawford \& Hunt (2022) Copyright 


\begin{tabular}{|c|c|c|}
\hline & & $\begin{array}{l}\text { multiplication, division) and may include a focus on complex } \\
\text { computation (algorithms) or basic fact retrieval. }\end{array}$ \\
\hline Fractions & Two Codes, See Below & $\begin{array}{l}\text { This includes interventions that focus on conceptual and procedural } \\
\text { fraction knowledge and includes topics like part-whole fractions, } \\
\text { measurement interpretation of fractions (fractions and number lines), } \\
\text { equivalent fractions, operations with fractions, etc. }\end{array}$ \\
\hline Decimals & Two Codes, See Below & $\begin{array}{l}\text { This includes interventions that focus on conceptual and procedural } \\
\text { decimal knowledge. Topics can include place value, magnitude } \\
\text { comparison, and computation. }\end{array}$ \\
\hline Percents & Two Codes, See Below & $\begin{array}{l}\text { This includes interventions that focus on conceptual and procedural } \\
\text { percent knowledge. }\end{array}$ \\
\hline $\begin{array}{l}\text { Word Problem } \\
\text { Solving }\end{array}$ & Two Codes, See Below & $\begin{array}{l}\text { This involves instruction that focuses on problems with a few sentences } \\
\text { describing a "real-life" situation which are translated into a mathematical } \\
\text { calculation. Interventions focused on word problems for computation or } \\
\text { proportions would be coded only as word problem solving. Word } \\
\text { problems could include computation with whole numbers, fractions, } \\
\text { decimals, ratios, etc. }\end{array}$ \\
\hline Problem Solving & Two Codes, See Below & $\begin{array}{l}\text { Problem solving involves using logic or reasoning to solve a task or a set } \\
\text { of related tasks for which there is no immediately apparent solution. } \\
\text { Interventions that focus on computations or word problem solving are } \\
\text { not included in problem solving. }\end{array}$ \\
\hline $\begin{array}{l}\text { Geometry \& } \\
\text { Measurement }\end{array}$ & Two Codes, See Below & $\begin{array}{l}\text { Geometry: These interventions may focus on spatial reasoning, shapes, } \\
\text { and transformations. At higher grade levels, this may also incorporate } \\
\text { argumentation and proof. Measurement: these interventions focus on } \\
\text { things like linear measurement, area, perimeter, angle measures, and } \\
\text { trigonometry. }\end{array}$ \\
\hline Algebra & Two Codes, See Below & $\begin{array}{l}\text { This will include topics such as variables, integers, equations and } \\
\text { inequalities, functions, and graphing on a Cartesian plane (x,y } \\
\text { coordinates). }\end{array}$ \\
\hline $\begin{array}{l}\text { Rate, Ratio, } \\
\text { Proportional } \\
\text { Reasoning }\end{array}$ & Two Codes, See Below & $\begin{array}{l}\text { These interventions focus on topics that involve composite units, } \\
\text { multiplicative comparisons, and covariation. Topics may include unit } \\
\text { rates, scale factors, and missing value proportions. }\end{array}$ \\
\hline
\end{tabular}

Nelson, Crawford \& Hunt (2022) Copyright 


\begin{tabular}{|l|l|l|}
\hline $\begin{array}{l}\text { Data } \\
\text { Analysis/Probability }\end{array}$ & Two Codes, See Below & $\begin{array}{l}\text { These interventions would focus on the collection and presentation of } \\
\text { data (e.g., graphing), central tendency (e.g., mean, median, mode) and } \\
\text { variability (e.g., MAD, SD, range), and likelihood of outcomes. }\end{array}$ \\
\hline
\end{tabular}

For each content area, you will code the following two codes:

\begin{tabular}{|c|c|c|}
\hline Variable & Code & Explanation \\
\hline $\begin{array}{l}\text { Content area is } \\
\text { identified or listed } \\
\text { in title, } \\
\text { Introduction, or } \\
\text { Method as a focus } \\
\text { of the synthesis. }\end{array}$ & $\begin{array}{l}\text { Select one: } \\
0=\text { No, not identified } \\
1=\text { yes, identified } \\
\text { Note, if you mark a } 0 \text { in this } \\
\text { column, it's automatically an } \\
\text { NA in the next column, for the } \\
\text { next code. }\end{array}$ & $\begin{array}{l}\text { Note: do not consider the abstract for this code as often the abstract } \\
\text { reports results, and this code is about the intent of the study. } \\
\text { - No = The content area (e.g., early numeracy) was not identified } \\
\text { by authors in the title, Introduction, or Method section as a focus } \\
\text { of the synthesis, however, the results presented may have } \\
\text { included information about the effects of the content area. In } \\
\text { other words, authors may not have been clear about the content } \\
\text { area focus of the intervention, or they presented results in } \\
\text { different content areas ad hoc, or as an afterthought. } \\
\text { - Yes = the synthesis focused on a content area and the authors } \\
\text { were clear about the focus somewhere in the title, Introduction, or } \\
\text { Methods section. For example, "The interventions in this meta- } \\
\text { analysis were required to focus on ratio and unit rate concepts." } \\
\text { Or the title of the synthesis clearly states "Synthesis of problem } \\
\text { solving interventions" or it is clearly detailed in the literature } \\
\text { review, research questions or purpose, inclusion criteria, etc. }\end{array}$ \\
\hline $\begin{array}{l}\text { Content area is } \\
\text { defined. }\end{array}$ & $\begin{array}{l}\text { Select one: } \\
\text { NA = not applicable (select } \\
\text { this option if you selected " } 0 \text { " } \\
\text { for the previous code) } \\
0=\text { No, not defined } \\
1=\text { yes, defined }\end{array}$ & $\begin{array}{l}\text { This code refers to whether or not the author or article provided how the } \\
\text { research team envisioned or defined the content area in relation to their } \\
\text { own synthesis. The article does not have to read, "we define } \\
\text { ratio/problem solving/early numeracy/etc. as..." but there does need to } \\
\text { be text provided for the reader to understand how the research team } \\
\text { defined the content area. } \\
\text { - Not applicable = the synthesis did not address this content area. } \\
\text { (select this option if you selected "0" for the previous code for } \\
\text { "identification") }\end{array}$ \\
\hline
\end{tabular}

Nelson, Crawford \& Hunt (2022) Copyright 


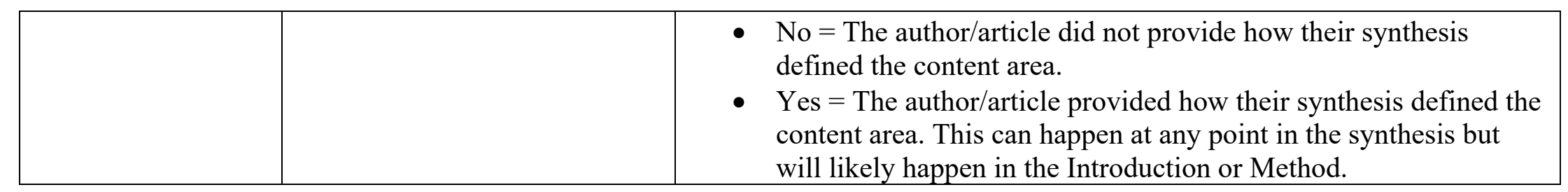

\section{Instructional Area Focus: As Stated Purpose of the Synthesis}

Note: These codes are related to the author's purpose of the synthesis and inclusion and exclusion criteria, not on the specific results or description of included studies in the meta-analysis.

\begin{tabular}{|l|l|l|}
\hline Variable & Code & Explanation \\
\hline $\begin{array}{l}\text { Components of } \\
\text { Systematic } \\
\text { Instruction }\end{array}$ & Two Codes, See Below & $\begin{array}{l}\text { Note: Study may state "explicit instruction" or "explicit and systematic } \\
\text { instruction" but they may also state common components such as: } \\
\text { modeling, stating lesson objectives, breaking down steps, guided practice } \\
\text { and independent practice, logically sequencing skills. }\end{array}$ \\
$\begin{array}{l}\text { Direct } \\
\text { Instruction }\end{array}$ & Two Codes, See Below \\
\hline $\begin{array}{l}\text { Feedback } \\
\text { corrective, } \\
\text { specific, } \\
\text { academic, } \\
\text { affirmative) }\end{array}$ & Two Codes, See Below & $\begin{array}{l}\text { Although monitoring students and providing feedback is a component of } \\
\text { explicit and systematic instruction, it is often separated for synthesis } \\
\text { purposes; so this is a different instructional strategy (below). }\end{array}$ \\
\hline $\begin{array}{l}\text { Cognitive } \\
\text { Strategy } \\
\text { Instruction }\end{array}$ & $\begin{array}{l}\text { Specifically identified as Direct Instruction as opposed to explicit and } \\
\text { systematic instruction. }\end{array}$ \\
& $\begin{array}{l}\text { This refers to interventions that are focused on considering the } \\
\text { effectiveness of forms of feedback to students. }\end{array}$ \\
\hline
\end{tabular}

Nelson, Crawford \& Hunt (2022) Copyright 


\begin{tabular}{|c|c|c|}
\hline & & $\begin{array}{l}\text { procedures with an emphasis on process modeling and verbalization of the } \\
\text { routine during the acquisition stage." }\end{array}$ \\
\hline $\begin{array}{l}\text { Concrete } \\
\text { Representations }\end{array}$ & Two Codes, See Below & $\begin{array}{l}\text { This refers to interventions that focus on using hands-on/physical } \\
\text { manipulatives to teach mathematical concepts or procedures. }\end{array}$ \\
\hline $\begin{array}{l}\text { Visual/Pictorial } \\
\text { Representations }\end{array}$ & Two Codes, See Below & $\begin{array}{l}\text { This refers to interventions that focus on using drawings or visual models } \\
\text { to teach mathematical concepts or procedures. These visuals can range } \\
\text { from informal (realistic drawings) to formal (abstract representations). }\end{array}$ \\
\hline CRA Framework & Two Codes, See Below & Note. This may be referred to as a graduated sequence of instruction. \\
\hline $\begin{array}{l}\text { SBI or SI } \\
\text { Framework }\end{array}$ & Two Codes, See Below & $\begin{array}{l}\text { Note, this is a specific framework and may be called "schema-instruction" } \\
\text { "schema-based instruction" or "schema broadening instruction." (though it } \\
\text { includes components such as using representations). For the purpose of this } \\
\text { review, SI/SBI may also be referred to as "priming the underlying problem } \\
\text { structure." From Powell (general description from a } 2013 \text { article, so Asha's } \\
\text { work might look more like the broadening definition used here as well): } \\
\text { Schema-based instruction, teaches students to use schematic diagrams to } \\
\text { solve word problems. The student reads a word problem, selects a schema } \\
\text { diagram into which the word problem fits, and uses the structure of the } \\
\text { diagram to solve the problem. Schema-broadening instruction is similar to } \\
\text { schema-based instruction in that students read the word problem and select } \\
\text { a schema (from the taught schema) to solve word problems. Schema- } \\
\text { broadening instruction differs from schema-based instruction because } \\
\text { students are taught to transfer their knowledge of problem types to } \\
\text { recognize problems with novel features (e.g., different format, additional } \\
\text { question, irrelevant information, unfamiliar vocabulary, or information } \\
\text { presented in charts, graphs, or pictures) as belonging to a problem type for } \\
\text { which they know a solution." }\end{array}$ \\
\hline $\begin{array}{l}\text { Peer-Assisted } \\
\text { Learning }\end{array}$ & Two Codes, See Below & $\begin{array}{l}\text { This may also be referred to as peer-mediated instruction, peer-tutoring, or } \\
\text { class wide peer-tutoring. }\end{array}$ \\
\hline $\begin{array}{l}\text { Computer- } \\
\text { assisted learning; } \\
\text { technology }\end{array}$ & Two Codes, See Below & $\begin{array}{l}\text { This refers to instructional modes that represent digital learning or } \\
\text { computer assisted learning/instruction. }\end{array}$ \\
\hline Other & Anecdotal & Please provide the description. \\
\hline
\end{tabular}

Nelson, Crawford \& Hunt (2022) Copyright 
For each instructional strategy, you will code the following two codes:

\begin{tabular}{|c|c|c|}
\hline Variable & Code & Explanation \\
\hline $\begin{array}{l}\text { Instructional } \\
\text { strategy is } \\
\text { identified or listed } \\
\text { in title, } \\
\text { Introduction, or } \\
\text { Method as a focus } \\
\text { of the synthesis. }\end{array}$ & $\begin{array}{l}\text { Select one: } \\
0=\text { No, not identified } \\
1=\text { yes, identified } \\
\text { Note, if you mark a } 0 \text { in this } \\
\text { column, it's automatically an } \\
\text { NA in the next column, for the } \\
\text { next code. }\end{array}$ & $\begin{array}{l}\text { Note: do not consider the abstract for this code as often the abstract reports } \\
\text { results, and this code is about the intent of the study. } \\
\text { - No = The instructional strategy (e.g., CRA) was not identified by } \\
\text { authors in the title, Introduction, or Method section as a focus of the } \\
\text { synthesis, however, the results presented may have included } \\
\text { information about the effects of this strategy. In other words, authors } \\
\text { may not have been clear about the instructional strategy focus of the } \\
\text { intervention, or they presented results of different strategies ad hoc, } \\
\text { or as an afterthought. Yes = the synthesis focused on this } \\
\text { instructional strategy and the authors were clear about the focus } \\
\text { somewhere in the title, Introduction, or Methods section. For } \\
\text { example, "The interventions in this meta-analysis were required to } \\
\text { use CRA." Or the title of the synthesis clearly states "Synthesis of } \\
\text { explicit instruction" or it is clearly detailed in the literature review, } \\
\text { research questions or purpose, inclusion criteria, etc. }\end{array}$ \\
\hline $\begin{array}{l}\text { Instructional } \\
\text { strategy is defined. }\end{array}$ & $\begin{array}{l}\text { Select one: } \\
\text { NA = not applicable (select } \\
\text { this option if you selected " } 0 \text { " } \\
\text { for the previous code) } \\
0=\text { No, not defined } \\
1=\text { yes, defined }\end{array}$ & $\begin{array}{l}\text { This code refers to whether or not the author or article provided how the } \\
\text { research team envisioned or defined the instructional strategy in relation to } \\
\text { their own synthesis. The article does not have to read, "we define CRA } \\
\text { as..." but there does need to be text provided for the reader to understand } \\
\text { how the research team defined the strategy. } \\
\text { - Not applicable = the synthesis did not address this instructional } \\
\text { strategy. (select this option if you selected "0" for the previous code } \\
\text { for "identification") } \\
\text { - } 0=\text { The author/article did not provide how their synthesis defined } \\
\text { the instructional strategy. } \\
\text { - } 1=\text { The author/article provided how their synthesis defined the } \\
\text { instructional strategy. This can happen at any point in the article. }\end{array}$ \\
\hline
\end{tabular}

Nelson, Crawford \& Hunt (2022) Copyright 


\section{RESULTS}

Student Participant Demographics Including MD and MLD Identification: Descriptive Results

\begin{tabular}{|c|c|c|}
\hline Variable & Code & Explanation \\
\hline Students Total $N$ & Number or "Not Reported" & $\begin{array}{l}\text { List the total number of student participants across studies; only } \\
\text { provide the number as it is presented in text or tables. Do not } \\
\text { perform your own calculations. }\end{array}$ \\
\hline $\begin{array}{l}\text { Students with LD or } \\
\text { MLD } N\end{array}$ & Number or NA/NR & $\begin{array}{l}\text { - List the total number of student participants across studies who } \\
\text { authors identified as having a Learning Disability (LD) or } \\
\text { Mathematics Learning Disability (MLD). For the purposes of } \\
\text { this study, this may also include "mathematics disability" or } \\
\text { "dyscalculia."; only provide the number as it is presented in text } \\
\text { or tables. Do not perform your own calculations. } \\
\text { This option is presented because not all studies will differentiate between } \\
\text { LD (any type) and MLD specifically. }\end{array}$ \\
\hline $\begin{array}{l}\text { Students with MLD } \\
\text { specifically } N\end{array}$ & Number or NA/NR & $\begin{array}{l}\text { List the total number of student participants across studies who } \\
\text { authors specifically identified as having a Mathematics } \\
\text { Learning Disability (MLD). For the purposes of this study, this } \\
\text { may also include "mathematics disability" or "dyscalculia."; only } \\
\text { provide the number as it is presented in text or tables. Do not } \\
\text { perform your own calculations. } \\
\text { This option is presented for studies that report, specifically, the number } \\
\text { of students that had a math learning disability, dyscalculia, or a math } \\
\text { disability (not just LD generally). }\end{array}$ \\
\hline Students with MD $N$ & Number or NA/NR & $\begin{array}{l}\text { - List the total number of student participants across studies who } \\
\text { authors identified as having a Mathematics Difficulty (MD); For } \\
\text { the purposes of this study, this may also include "low } \\
\text { achievement in mathematics" or "struggling in mathematics." } \\
\text { Only provide the number as it is presented in text or tables. Do } \\
\text { not perform your own calculations. }\end{array}$ \\
\hline
\end{tabular}

Nelson, Crawford \& Hunt (2022) Copyright 


\begin{tabular}{|c|c|c|}
\hline & & $\begin{array}{l}\text { This option is presented for studies that report, specifically, the number } \\
\text { of students that had risk in math, math difficulty, or were low achieving } \\
\text { in math. }\end{array}$ \\
\hline $\begin{array}{l}\text { Students with LD/MLD } \\
\text { or MD } N \text { and Authors } \\
\text { don't provide separate } \\
\text { data }\end{array}$ & Number or NA/NR & $\begin{array}{l}\text { Only use this code if authors included students with or at-risk of } \\
\text { learning disabilities AND mathematics difficulty and authors did } \\
\text { not report the separate sample sizes for LD versus LD. } \\
\text { - List the total number of students with LD or MD. } \\
\text { Sometimes, studies include students with learning disabilities and math } \\
\text { difficulty in the same sample, but the authors do not provide different } \\
\text { sample sizes for LD/MLD compared to Math Difficulty. This option is } \\
\text { presented for studies that report, the number of students with LD/MLD } \\
\text { and MD without providing disaggregated data. }\end{array}$ \\
\hline $\begin{array}{l}\text { Students with } \\
\text { Disabilities other than } \\
\text { LD/MLD } N\end{array}$ & Number or NA/NR & $\begin{array}{l}\text { List the total number of student participants across studies who } \\
\text { authors identified as having other types of disabilities other than } \\
\text { LD or MLD. This may include ADHD, developmental } \\
\text { disability, OHI, ASD, etc. Only provide the number as it is } \\
\text { presented in text or tables. Do not perform your own calculations. } \\
\text { Some studies might also include a small number of students with other } \\
\text { types of disabilities. This column is specifically for disabilities other than } \\
\text { LD and MLD. }\end{array}$ \\
\hline $\begin{array}{l}\text { Students who are } \\
\text { Typically Achieving } N\end{array}$ & Number or NA/NR & $\begin{array}{l}\text { List the total number of student participants across studies who } \\
\text { authors identified as typically achieving. Only provide the } \\
\text { number as it is presented in text or tables. Do not perform your } \\
\text { own calculations. } \\
\text { Some studies might also include typically achieving students. This } \\
\text { column is to report the number of typically achieving students in the } \\
\text { sample. }\end{array}$ \\
\hline $\begin{array}{l}\text { Notes about Sample } \\
\text { Size }\end{array}$ & Anecdotal & $\begin{array}{l}\text { - Provide any detail related to the sample size, such as if } \\
\text { information was not provided in a straightforward manner and } \\
\text { you need to explain the number }\end{array}$ \\
\hline
\end{tabular}

Nelson, Crawford \& Hunt (2022) Copyright 


\begin{tabular}{|l|l|l|}
\hline Mean Age or Range & Number (years) & $\begin{array}{l}\text { List the mean age of participants (years, months; } 8,11 \text { for } 8 \\
\text { years, 11 months) if it is provided; this refers to the descriptive } \\
\text { results of included studies. }\end{array}$ \\
\hline $\begin{array}{l}\text { Specific Grades } \\
\text { Included }\end{array}$ & $\begin{array}{l}\text { Select one for each grade } \\
\text { level: } \\
\begin{array}{l}\text { There will be a cell for } \\
\text { each grade level PreK }- \\
12 .\end{array}\end{array}$ & $\begin{array}{l}\text { Mark 1 in the cell if this grade level is represented in the } \\
\text { synthesis; this should be specific information about the grade } \\
\text { levels such as provided in a table or sample sizes per grade level } \\
\text { in the text }\end{array}$ \\
$\begin{array}{l}\text { If the synthesis only provides a range, then you put a mark in } \\
\text { each grade represented by the range. For example, K-2 would } \\
\text { receive a 1 in K, 1, and 2. }\end{array}$
\end{tabular}

\section{Methodological Information and Results}

\begin{tabular}{|c|c|c|}
\hline Variable & Code & Explanation \\
\hline Type of Synthesis & $\begin{array}{l}\text { Select one: } \\
0=\text { meta-analysis } \\
1=\text { best-evidence synthesis } \\
2=\text { systematic review or } \\
\text { synthesis }\end{array}$ & $\begin{array}{l}\text { Codes defined: } \\
\text { - } 0 \text { = authors conducted a meta-analysis (a summary effect is } \\
\text { reported) } \\
\text { - } 1=\text { authors conducted a "best evidence synthesis" or "review of the } \\
\text { evidence" which typically includes a review of the quality of the } \\
\text { studies, and may also include reporting a summary effect. } \\
\text { - } 2=\text { authors completed a systematic review in which they outline } \\
\text { their search procedures and may or may not report individual } \\
\text { summary effects for studies or possibly a range of effect sizes across } \\
\text { studies; this may also be referred to as a "review of the literature" }\end{array}$ \\
\hline Designs Included & $\begin{array}{l}\text { Select one: } \\
0=\text { Not reported; not clear } \\
1=\text { SCD only } \\
2=\text { group design only } \\
3=\text { SCD and group design }\end{array}$ & $\begin{array}{l}\text { Codes defined as: } \\
-\quad 0=\text { It is not reported and it is not able to be determined what designs } \\
\text { were included in the study } \\
\text { - } 1 \text { = Single-case design (SCD) studies only were included } \\
\text { - } 2 \text { = group design only were included (experimental and/or quasi- } \\
\text { experimental) }\end{array}$ \\
\hline
\end{tabular}

Nelson, Crawford \& Hunt (2022) Copyright 


\begin{tabular}{|c|c|c|}
\hline & & - $3=\mathrm{SCD}$ and group design were both included \\
\hline $\begin{array}{l}\text { Total Number of } \\
\text { Studies }\end{array}$ & Number & $\begin{array}{l}\text { Total number of studies that the authors decided to include in the synthesis; } \\
\text { you may need to count the number from a table if it is not provided in text } \\
\text { (also, check the abstract, it is often there) }\end{array}$ \\
\hline Type of Effect Size & $\begin{array}{l}\text { Select all that apply: } \\
0=\text { Not Reported } \\
1=\text { Cohen's d ES } \\
2=\text { Hedges g ES } \\
3=\text { Eta-squared ES } \\
4=\text { Tau U } \\
5=\text { PND (percent of non- } \\
\text { overlapping data) } \\
6=\text { PAND (percentage of all } \\
\text { non-overlapping data) } \\
7=\text { SMD (standard mean } \\
\text { difference) } \\
8=\text { IRD (Improvement Rate } \\
\text { Difference) } \\
9=\text { LLR = log response ratio } \\
10=\text { Phi } \\
11=\text { PEM (percentage of data } \\
\text { points exceeding the median) } \\
12=\text { Other } \\
\text { Separate responses using a } \\
\text { semi-colon (e.g., " } 1 ; 3 ; 4 " \text { ) }\end{array}$ & $\begin{array}{l}\text { What type of effect size(s) did researchers report for the studies (this is after } \\
\text { any conversion or transformation of data). } \\
\text { Note: codes } 1-3 \text { are common for group design studies; codes } 4-11 \text { are } \\
\text { common for SCD. } \\
\text { Note this refers specifically to how authors reported aggregated effect sizes; } \\
\text { if effectiveness is measured in some other capacity (e.g., social validity) } \\
\text { that information will be captured elsewhere. }\end{array}$ \\
\hline $\begin{array}{l}\text { Effect Size } \\
\text { Aggregation }\end{array}$ & Anecdotal and Copy and Paste & $\begin{array}{l}\text { If studies reported effect sizes, how were effect sizes within the same study } \\
\text { aggregated. In other words, did the authors calculate a composite effect } \\
\text { sizes (they took all outcome measures and reported } 1 \text { effect sizes for each } \\
\text { study as a representative effect size), they selected } 1 \text { measure/effect size as } \\
\text { the primary measure (if so, was it a proximal measure, norm-referenced, or } \\
\text { a specific content area?), or they accounted for dependency of effect sizes. }\end{array}$ \\
\hline
\end{tabular}

Nelson, Crawford \& Hunt (2022) Copyright 


\begin{tabular}{|c|c|c|}
\hline & & $\begin{array}{l}\text { An example of a composite effect sizes: "In the case where a study used } \\
\text { multiple outcome measures, we calculated the mean effect size across } \\
\text { measures." } \\
\text { An example of the primary measure: "When researchers used more than one } \\
\text { math measure, we identified a primary outcome measure that was the best } \\
\text { representation of the construct of early numeracy, as the purpose of this } \\
\text { meta-analysis was to determine the effect of early numeracy interventions } \\
\text { on math performance." } \\
\text { An example of accounting for dependency of effect sizes: "All eligible, } \\
\text { independent effect sizes were included from each study, resulting in some } \\
\text { studies contributing multiple effect sizes when several math outcomes were } \\
\text { reported. Therefore, to account for the statistical dependencies of correlated } \\
\text { effects, random effects robust standard estimation was used." }\end{array}$ \\
\hline $\begin{array}{l}\text { Long-term } \\
\text { Effectiveness of the } \\
\text { Intervention }\end{array}$ & $\begin{array}{l}\text { Select all that apply (1 and } 2 \\
\text { could both be selected if } \\
\text { appropriate): } \\
0=\text { no } \\
1=\text { yes, summary effect for } \\
\text { delayed post-test, maintenance } \\
2=\text { yes, individual study effect } \\
\text { for delayed post-test, } \\
\text { maintenance } \\
3=\text { reported other information } \\
\text { about long-term effectiveness }\end{array}$ & $\begin{array}{l}\text { This code refers to whether or not authors evaluated summary effects } \\
\text { beyond typical post-test, such as with a delayed post-test analysis. This is } \\
\text { only a code for summary or individual effects. } \\
\text { - No = no long-term effects, maintenance, or delayed-post-test results } \\
\text { were reported as results } \\
\text { - Yes, summary effects = an aggregate effect for long-term } \\
\text { effectiveness was reported across studies } \\
\text { - Yes, individual effects = individual long-term effects were reported } \\
\text { - } 3=\text { Authors reported other information about long-term measures } \\
\text { when present in included studies (presence of maintenance tests, } \\
\text { visual inspection, etc.) }\end{array}$ \\
\hline $\begin{array}{l}\text { Outcome Measures } \\
\text { Presented }\end{array}$ & $\begin{array}{l}\text { Select all that apply: } \\
0=\text { not reported } \\
1=\text { achievement outcomes } \\
\text { (effect sizes) } \\
2=\text { strategy use }\end{array}$ & $\begin{array}{l}\text { Codes defined: } \\
\text { This code refers to how authors defined effectiveness of the intervention. } \\
\text { This code indicates what outcome measures were reported in any format. In } \\
\text { other words, what outcome data were authors of the synthesis reporting } \\
\text { (often it's just achievement data). This can be summary effects, individual }\end{array}$ \\
\hline
\end{tabular}

Nelson, Crawford \& Hunt (2022) Copyright 


\begin{tabular}{|c|c|c|}
\hline & $\begin{array}{l}3=\text { attitude, anxiety } \\
4=\text { engagement } \\
5=\text { student social validity } \\
6=\text { teacher social validity } \\
7=\text { social validity (not } \\
\text { specified) }\end{array}$ & $\begin{array}{l}\text { effects, frequencies, or any other form of reporting on the presence of these } \\
\text { measures. } \\
\text { - } 0=\text { it is not clear from the study how authors were reporting } \\
\text { effectiveness } \\
\text { - } 1=\text { any math achievement data, such as problems correct, score on a } \\
\text { standardized measure, pre to posttest gains, CBMs, etc. } \\
\text { - } 2=\text { any data about students' growth or difference in use of strategies } \\
\text { as a result of the intervention } \\
\text { - } 3=\text { any data about students' math attitude or anxiety as a result of } \\
\text { the intervention } \\
\text { - } 4=\text { any data about students' engagement in math as a result of the } \\
\text { intervention } \\
\text { - } 5=\text { any data about students' perceptions of the intervention, such as } \\
\text { usefulness of the lessons, likeness of the lessons, etc. } \\
\text { - } 6=\text { any data about teachers' perceptions of the intervention, such as } \\
\text { usefulness of the lessons, likeness of the lessons, this might also be } \\
\text { feasibility or cost effectiveness data } \\
\text { - } 7=\text { social validity data were captured but it's not clear or specified } \\
\text { from who }\end{array}$ \\
\hline $\begin{array}{l}\text { Proximal and Distal } \\
\text { Outcomes }\end{array}$ & $\begin{array}{l}\text { Select all that apply: } \\
\text { NA = not applicable } \\
0=\text { not able to determine } \\
1=\text { proximal measures } \\
2=\text { distal measures } \\
3=\text { CBMs } \\
4=\text { Norm-referenced } \\
5=\text { researcher developed }\end{array}$ & $\begin{array}{l}\text { What types of measures did authors use to calculate effect sizes? Note that } \\
\text { some of the options are not mutually exclusive. Two codes may apply if the } \\
\text { measure or measures are explicitly identified as such (e.g., a proximal CBM } \\
\text { is coded as both but a CBM with no other information would just be coded } \\
\text { as CBM). (This is ONLY about which effect sizes are reported, either } \\
\text { summary effects OR individual effects. This is NOT based on inclusion } \\
\text { criteria - this is only what effect sizes are reported in the results.) } \\
\text { - NA = authors did not calculate any effect sizes (this would only be a } \\
\text { handful of studies) } \\
\text { - Proximal = authors stated that they calculated effect sizes using } \\
\text { proximal measures (measures closely aligned to the intervention) } \\
\text { Distal = authors stated that they calculated effect sizes using distal } \\
\text { measures (measures not aligned to the intervention) }\end{array}$ \\
\hline
\end{tabular}

Nelson, Crawford \& Hunt (2022) Copyright 


\begin{tabular}{|c|c|c|}
\hline & & $\begin{array}{l}\text { - CBMs = authors used data from curriculum based measures to } \\
\text { calculate effect sizes } \\
\text { - Norm-referenced = authors used standardized norm-referenced tests } \\
\text { such as TEMA, WJ, SAT-10, SESAT, etc. to calculate effect sizes } \\
\text { - Researcher-developed = authors considered researcher created } \\
\text { measures to calculate effect sizes, also called experimenter } \\
\text { developed. } \\
\text { If the measure is only identified as "standardized" with no other } \\
\text { information, code this as 0-not able to determine. }\end{array}$ \\
\hline $\begin{array}{l}\text { Outcome Measure } \\
\text { Results Information }\end{array}$ & Anecdotal & $\begin{array}{l}\text { Use this column to report any specific information. For example, } \\
\text { maybe social validity data were only presented for SCD studies, or } \\
\text { strategy use was only reported for a handful of studies. }\end{array}$ \\
\hline $\begin{array}{l}\text { Effect Sizes and } \\
\text { Results }\end{array}$ & Number & $\begin{array}{l}\text { Record all effect sizes reported by authors; this includes effect sizes that are } \\
\text { summary effects, and for subgroup analyses such as for different content } \\
\text { areas, instructional strategies, and groups of students (e.g., LD, MLD, MD). }\end{array}$ \\
\hline
\end{tabular}

\section{Instructional Strategies}

For each instructional area that is mentioned in the Results or Discussion, you will select if any results were presented. This coding should happen regardless of what the authors specified was the focus of their synthesis. This can be effect sizes, frequency counts of the number of studies that address a strategy, etc.

\begin{tabular}{|c|c|c|}
\hline Variable & Code & Explanation \\
\hline $\begin{array}{l}\text { Components of } \\
\text { Explicit and } \\
\text { Systematic } \\
\text { Instruction }\end{array}$ & $\begin{array}{l}\text { Select all that apply: } \\
0=\text { no results reported } \\
1=\text { summary effect sizes } \\
2=\text { individual study effect sizes } \\
3=\text { frequency counts } \\
4=\text { other results (e.g., qualitative) }\end{array}$ & $\begin{array}{l}\text { Note: Study may state "explicit instruction" or "explicit and systematic } \\
\text { instruction" but they may also state common components such as: } \\
\text { modeling, breaking down steps, guided practice and independent practice, } \\
\text { logically sequencing skills. } \\
\text { - } 0 \text { = No results (summary effects, individual study effects, } \\
\text { qualitative information, or frequency counts) were reported for this } \\
\text { instructional strategy. } \\
\text { - } 1=\text { Yes, there is a summary effect size for this instructional } \\
\text { strategy. }\end{array}$ \\
\hline
\end{tabular}

Nelson, Crawford \& Hunt (2022) Copyright 


\begin{tabular}{|c|c|c|}
\hline & & $\begin{array}{l}\text { - } 2=\text { yes, there are individual study effect sizes linked with this } \\
\text { instructional strategy (could be in text or in a table). } \\
\text { - } 3=\text { frequency counts were reported, such as the number of studies } \\
\text { in the synthesis that focused on this instructional strategy } \\
\text { - } 4=\text { other results including qualitative synthesis of the instructional } \\
\text { strategy or individual summaries of studies that used this } \\
\text { instructional strategy. }\end{array}$ \\
\hline $\begin{array}{l}\text { Direct } \\
\text { Instruction }\end{array}$ & $\begin{array}{l}\text { Select all that apply: } \\
0=\text { no results reported } \\
1=\text { summary effect sizes } \\
2=\text { individual study effect sizes } \\
3=\text { frequency counts } \\
4=\text { other results (e.g., qualitative) }\end{array}$ & $\begin{array}{l}\text { Specifically identified as Direct Instruction as opposed to Explicit and } \\
\text { Systematic Instruction. }\end{array}$ \\
\hline $\begin{array}{l}\text { Feedback } \\
\text { (corrective, } \\
\text { specific, } \\
\text { academic, } \\
\text { affirmative) }\end{array}$ & $\begin{array}{l}\text { Select all that apply: } \\
0=\text { no results reported } \\
1=\text { summary effect sizes } \\
2=\text { individual study effect sizes } \\
3=\text { frequency counts } \\
4=\text { other results (e.g., qualitative) }\end{array}$ & $\begin{array}{l}\text { This refers to interventions that are focused on considering the } \\
\text { effectiveness of forms of feedback to students. }\end{array}$ \\
\hline $\begin{array}{l}\text { Cognitive } \\
\text { Strategy } \\
\text { Instruction }\end{array}$ & $\begin{array}{l}\text { Select all that apply: } \\
0=\text { no results reported } \\
1=\text { summary effect sizes } \\
2=\text { individual study effect sizes } \\
3=\text { frequency counts } \\
4=\text { other results (e.g., qualitative) }\end{array}$ & $\begin{array}{l}\text { This may include: cognitive strategy instruction, self-monitoring, self- } \\
\text { regulation, self-questioning, meta-cognition. Definition from Montague's } \\
\text { work: "the intervention presents a routine for mathematical problem } \\
\text { solving that incorporates both cognitive processes and metacognitive } \\
\text { strategies for solving problems and utilizes explicit instructional } \\
\text { procedures with an emphasis on process modeling and verbalization of the } \\
\text { routine during the acquisition stage." }\end{array}$ \\
\hline $\begin{array}{l}\text { Concrete } \\
\text { Representations }\end{array}$ & $\begin{array}{l}\text { Select all that apply: } \\
0=\text { no results reported } \\
1=\text { summary effect sizes } \\
2=\text { individual study effect sizes } \\
3=\text { frequency counts }\end{array}$ & $\begin{array}{l}\text { This refers to interventions that focus on using hands-on manipulatives to } \\
\text { teach mathematical concepts or procedures. }\end{array}$ \\
\hline
\end{tabular}

Nelson, Crawford \& Hunt (2022) Copyright 


\begin{tabular}{|c|c|c|}
\hline & $4=$ other results (e.g., qualitative) & \\
\hline $\begin{array}{l}\text { Visual/Pictorial } \\
\text { Representations }\end{array}$ & $\begin{array}{l}\text { Select all that apply: } \\
0=\text { no results reported } \\
1=\text { summary effect sizes } \\
2=\text { individual study effect sizes } \\
3=\text { frequency counts } \\
4=\text { other results (e.g., qualitative) }\end{array}$ & $\begin{array}{l}\text { This refers to interventions that focus on using drawings or visual models } \\
\text { to teach mathematical concepts or procedures. These visuals can range } \\
\text { from informal (realistic drawings) to formal (abstract representations). }\end{array}$ \\
\hline CRA Framework & $\begin{array}{l}\text { Select all that apply: } \\
0=\text { no results reported } \\
1=\text { summary effect sizes } \\
2=\text { individual study effect sizes } \\
3=\text { frequency counts } \\
4=\text { other results (e.g., qualitative) }\end{array}$ & Note. This may be referred to as a graduated sequence of instruction. \\
\hline $\begin{array}{l}\text { SBI or SI } \\
\text { Framework }\end{array}$ & $\begin{array}{l}\text { Select all that apply: } \\
0=\text { no results reported } \\
1=\text { summary effect sizes } \\
2=\text { individual study effect sizes } \\
3=\text { frequency counts } \\
4=\text { other results (e.g., qualitative) }\end{array}$ & $\begin{array}{l}\text { Note, this is a specific framework and may be called "schema-instruction" } \\
\text { "schema-based instruction" or "schema broadening instruction." (though it } \\
\text { includes components such as using representations). For the purpose of this } \\
\text { review, SI/SBI may also be referred to as "priming the underlying problem } \\
\text { structure." From Powell (general description from a } 2013 \text { article, so Asha's } \\
\text { work might look more like the broadening definition used here as well): } \\
\text { Schema-based instruction, teaches students to use schematic diagrams to } \\
\text { solve word problems. The student reads a word problem, selects a schema } \\
\text { diagram into which the word problem fits, and uses the structure of the } \\
\text { diagram to solve the problem. Schema-broadening instruction is similar to } \\
\text { schema-based instruction in that students read the word problem and select } \\
\text { a schema (from the taught schema) to solve word problems. Schema- } \\
\text { broadening instruction differs from schema-based instruction because } \\
\text { students are taught to transfer their knowledge of problem types to } \\
\text { recognize problems with novel features (e.g., different format, additional } \\
\text { question, irrelevant information, unfamiliar vocabulary, or information }\end{array}$ \\
\hline
\end{tabular}

Nelson, Crawford \& Hunt (2022) Copyright 


\begin{tabular}{|c|c|c|}
\hline & & $\begin{array}{l}\text { presented in charts, graphs, or pictures) as belonging to a problem type for } \\
\text { which they know a solution." }\end{array}$ \\
\hline $\begin{array}{l}\text { Peer-Assisted } \\
\text { Learning }\end{array}$ & $\begin{array}{l}\text { Select all that apply: } \\
0=\text { no results reported } \\
1=\text { summary effect sizes } \\
2=\text { individual study effect sizes } \\
3=\text { frequency counts } \\
4=\text { other results (e.g., qualitative) }\end{array}$ & $\begin{array}{l}\text { This may also be referred to as peer-mediated instruction, peer-tutoring, or } \\
\text { class wide peer-tutoring. }\end{array}$ \\
\hline $\begin{array}{l}\text { Computer- } \\
\text { Assisted } \\
\text { Learning; } \\
\text { Technology; } \\
\text { Digital }\end{array}$ & $\begin{array}{l}\text { Select all that apply: } \\
0=\text { no results reported } \\
1=\text { summary effect sizes } \\
2=\text { individual study effect sizes } \\
3=\text { frequency counts } \\
4=\text { other results (e.g., qualitative) }\end{array}$ & $\begin{array}{l}\text { This refers to instructional modes that represent digital learning or } \\
\text { computer assisted learning/instruction. }\end{array}$ \\
\hline Other & Anecdotal & Please provide the description. \\
\hline
\end{tabular}

\section{How Effectiveness was Measured and Reported}

- There are a few other codes throughout related to effectiveness in different sections. They are highlighted in blue.

\begin{tabular}{|l|l|l|}
\hline Variable & Code & Explanation \\
\hline EBPs Focus? & $\begin{array}{l}\text { Select one: } \\
0=\text { no } \\
1=\text { yes }\end{array}$ & $\begin{array}{l}\text { This code refers to if the synthesis attempted to identify a practice as an } \\
\text { evidence-based practice. } \\
\text { No=the purpose of the study was not to identify a practice as EBP (this is } \\
\text { many of the meta-analyses) } \\
\text { Yes = yes, the purpose of the article (usually a quality review) was to } \\
\text { identify a practice as EBP }\end{array}$ \\
$\begin{array}{l}\text { Was the practice } \\
\text { identified as } \\
\text { EBP? }\end{array}$ & $\begin{array}{l}\text { Select one: } \\
\text { NA } \\
0=\text { no } \\
1=\text { yes }\end{array}$ & $\begin{array}{l}\text { If you coded a 1 above, was the practice actually identified as EBP at the } \\
\text { conclusion of the study? } \\
\text { NA = not applicable because you selected a code of }) \text { above }\end{array}$ \\
\hline
\end{tabular}

Nelson, Crawford \& Hunt (2022) Copyright 


\begin{tabular}{|l|l|l|}
\hline & & $\begin{array}{l}\text { No = the authors determined that the practice was not EBP or there wasn't } \\
\text { enough evidence } \\
\text { Yes = according to the results of the study, the practice is EBP }\end{array}$ \\
\hline $\begin{array}{l}\text { Evidence } \\
\text { Indicators }\end{array}$ & $\begin{array}{l}\text { Copy and paste information about what measure, scale, quality indicators } \\
\text { the authors used to determine if the practice was EBP. Some studies will } \\
\text { include quality indicators without actually identifying a practice as } \\
\text { evidence-based. Only quality indicators used to identify an EBP should be } \\
\text { reported here. }\end{array}$ \\
\hline
\end{tabular}

Nelson, Crawford \& Hunt (2022) Copyright 